Alexander Patrick, M. (Orcid ID: 0000-0003-3559-2539)

Tedesco Marco (Orcid ID: 0000-0002-7549-9307)

Koenig Lora, S (Orcid ID: 0000-0002-6057-8483)

Fettweis Xavier (Orcid ID: 0000-0002-4140-3813)

\title{
Evaluating a regional climate model simulation of Greenland ice sheet snow and firn density for improved surface mass balance estimates
}

\section{P. M. Alexander ${ }^{1,2}$, M. Tedesco ${ }^{1,2}$, L. Koenig $^{3}$, and X. Fettweis ${ }^{4}$}

${ }^{1}$ Lamont-Doherty Earth Observatory, Columbia University, Palisades, NY, USA.

${ }^{2}$ NASA Goddard Institute for Space Studies, New York, NY, USA.

${ }^{3}$ National Snow and Ice Data Center, University of Colorado, Boulder, CO, USA

${ }^{4}$ University of Liège, Liège, Belgium

Corresponding author: Patrick Alexander (pma2107@1deo.columbia.edu)

\section{Key Points:}

- We evaluate simulated Greenland snow and firn density from the MAR regional climate model to address surface mass balance uncertainty.

- A $-10 \%$ model bias in density of the top $1 \mathrm{~m}$ could lead to a $-10 \%$ SMB bias from remote sensing estimates in dry snow areas.

- Meltwater processes produce a positive model density bias of $10 \%$ for 1 to $10 \mathrm{~m}$ depth, limiting the snow liquid water retention capacity.

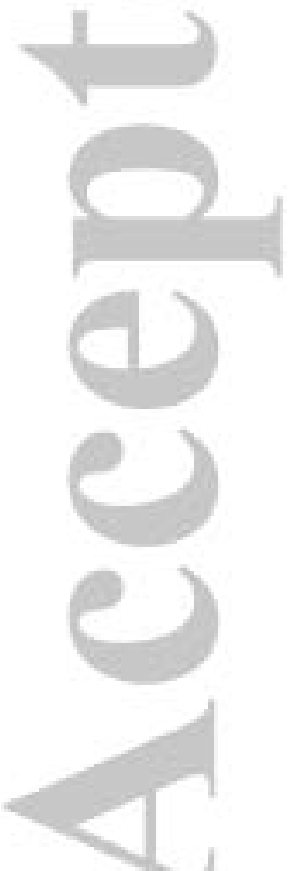

This article has been accepted for publication and undergone full peer review but has not been through the copyediting, typesetting, pagination and proofreading process which may lead to differences between this version and the Version of Record. Please cite this article as doi: 10.1029/2019GL084101 


\section{Abstract}

Modeling vertical profiles of snow and firn density near the surface of the Greenland ice sheet (GrIS) is key to estimating GrIS mass balance, and by extension, global sea level change. To understand sources of error in simulated GrIS density, we compare GrIS density profiles from a leading regional climate model with coincident in situ measurements. We identify key contributors to model density and mass balance biases, including underestimated simulated fresh snow density (which leads to underestimation of density in the top $1 \mathrm{~m}$ of snow by $\sim 10 \%$ ). In areas undergoing frequent melting, positive density biases (of $7 \%$ in the top $1 \mathrm{~m}$, and $10 \%$ between 1 and $10 \mathrm{~m}$ ) are likely associated with errors in representing meltwater production, retention and refreezing. The results highlight the importance of accurately capturing fresh snow density and meltwater processes in models used to estimate GrIS mass balance change.

\section{Plain Language Summary}

The density of snow (and firn - high density compacted snow) on the Greenland ice sheet is an important parameter because it is used to convert changes in ice sheet thickness measured from satellite and airborne instruments into changes in mass, which is key to estimating the ice sheet contribution to sea level change. The simulation of density in climate models such as the one examined in this study is therefore important to making estimates of current and future sea level change from ice sheets. In this study we compare snow density values simulated by a climate model with a large collection of measurements taken on the Greenland ice sheet. We find that the model tends to underestimate density near the surface in dry regions, and overestimates it where there is substantial meltwater produced during summer months that subsequently refreezes, which could lead to errors in mass change estimates. We provide suggestions regarding model adjustments that will likely improve the simulation of snow density and which are likely also relevant to other climate model simulations.

\section{Introduction}

The density of snow and firn over the Greenland and Antarctic ice sheets (GrIS and AIS) is crucial for understanding ice sheet contribution to changing sea level (e.g. Shepherd et al., 2018; Mouginot et al., 2019). Spatially and temporally distributed estimates of snow and firn density and densification are required to convert observed thickness changes from satellite laser and radar altimetry (e.g. ICEsat-2; Markus et al., 2017; and Cryosat-2; Helm et al., 2014), and from radar-derived estimates of annual or seasonal snow accumulation (e.g. 
Koenig et al., 2016; Medley et al., 2013) into mass changes (e.g. Zwally et al., 2011, 2005). Due to the sparse distribution of snow and firn density measurements, firn densification models (FDMs; e.g. Kuipers Munneke et al., 2015; Ligtenberg et al., 2011; Li and Zwally, 2011) are generally used to simulate densification and perform the thickness to mass change conversion.

For the Greenland ice sheet, firn density can also influence the storage of meltwater in firn aquifers (e.g. Harper et al., 2012; Forster et al., 2013; Koenig et al., 2014). Higher snow and firn density enhances surface runoff by preventing percolation of new meltwater into the snow and firn (Machguth et al., 2016; Noël et al., 2017), and surface snow density can affect the wind-driven transport of snow, particularly over Antarctica (Lenaerts et al., 2012; Agosta et al., 2019), and near-surface temperature variability in winter (Fréville et al., 2014).

Evaluation of models simulating snow density is essential to improving estimates of Greenland mass change. Previous publications have focused on stand-alone firn densification models (FDMs) or snow models (e.g. Arthern et al., 2010; Ligtenberg et al., 2011; Kuipers Munneke et al., 2015; Steger et al., 2017; Ligtenberg et al., 2018). Fewer studies (Vandecrux et al., 2019; Langen et al., 2017; Koenig et al. 2016) have focused on regional climate model (RCM) simulations, which unlike FDMs, capture two-way surface atmosphere feedbacks. In order to identify RCM biases and key processes responsible for them, we perform a broadscale evaluation of snow density over the Greenland ice sheet (GrIS) simulated by one of the leading RCMs used to estimate ice sheet SMB, the Modèle Atmosphérique Regionale (MAR; Fettweis et al., 2017). We test different model configurations and identify several key biases and factors contributing to them that are common to other RCMs and FDMs and which could contribute to substantial errors in GrIS mass balance estimates.

\section{Data and Methods}

2.1 MAR regional climate model

The MAR RCM (e.g. Fettweis et al., 2017; Gallée and Schayes, 1994; DeRidder and Schayes, 1997) simulates the coupled surface-atmosphere system within a regional domain forced at the lateral boundaries and ocean surface with climate reanalysis or global climate model outputs. MAR agrees well with SMB-related quantities over the GrIS (e.g. Fettweis et al., 2017, 2011; Colgan et al., 2015). The MAR snow model (CROCUS; Brun et al., 1992) 
simulates a fixed number of snow, ice, or firn layers of variable thickness, and transfers mass and energy between them. Snow densification occurs through mechanical compaction from overlying snow, and through liquid water retention (up to a maximum percentage of pore space, the irreducible water saturation) and refreezing. Section S1 of the supplemental information supplies further details on the densification process. We focus our analysis on the latest version of MAR, v3.9.3, which features minor fixes and tuning relative to MAR v3.5.2 (Fettweis et al., 2017). MAR v3.9.3 simulations are forced by the European Center for Medium Range Weather Forecasts Interim Reanalysis (ERA-Interim; Dee et al., 2011) for 1980 through 2017, and are run at spatial resolutions of 7.5, 15, 20, and $25 \mathrm{~km}$. (For most of the analysis we focus on the $7.5 \mathrm{~km}$ resolution simulation.) One additional $20 \mathrm{~km}$ resolution simulation is forced with data from the National Centers for Environmental Prediction National Center for Atmospheric Research Reanalysis version 1 (NCEP-NCARv1; Kalnay et al., 1996). We also compare simulations at $25 \mathrm{~km}$ for MAR versions 3.9.3, 3.5 .2 and 3.2 (e.g. used by Alexander et al., 2014). Relevant differences between the simulations are the minimum initial fresh snow density, set to $0.2 \mathrm{~g} / \mathrm{cm}^{3}$ for $\mathrm{v} 3.9$ and $\mathrm{v} 3.5 .2$, and $0.05 \mathrm{~g} / \mathrm{cm}^{3}$ for v3.2, the irreducible water saturation, set to $10 \%$ in v3.9, and $7 \%$ in v3.5.2 and v.3.2, and the density at which pores are assumed to close off, eliminating liquid water retention $(0.83$ $\mathrm{g} / \mathrm{cm}^{3}$ in v3.2, and a range between 0.83 and $0.9 \mathrm{~g} / \mathrm{cm}^{3}$ in $\mathrm{v} 3.5 .2$ and $\mathrm{v} 3.9$ ).

\subsection{The SUMup community dataset}

We compare MAR with snow and firn density measurements from the Surface Mass Balance and Snow on Sea Ice Working Group (SUMup) dataset (Koenig and Montgomery, 2018; Montgomery et al., 2018), which is a compilation of density measurements from multiple sources (Alley, 1999; Baker, 2016; Benson, 2013, 2017; Bolzan and Strobel, 1999a-g, 2001a,b; Chellman, 2016; Conway 2003; Cooper et al., 2018; Dibb and Fahnestock, 2004; Dibb et al., 2007; Harper et al., 2012; Hawley et al., 2014; Koenig et al., 2014; Vandecrux et al., 2019; Machguth et al., 2016; Mayewski and Whitlow, 2009a-d; Miège et al., 2013; Miller and Schwager, 2000a,b; Mosley-Thompson et al., 2001; Ohmura, 1991, 1992; Renaud, 1959; Schaller et al., 2016, 2017; Wilhelms, 2000a-d). The 2018 version of the SUMup dataset contains 761 unique profiles collected at 633 locations on the Greenland ice sheet. It contains measurements collected using a variety of methods as described by Montgomery et al. (2018). The data for the GrIS span 1950 to present, but we only utilized data beginning 1980 as this was the starting point for the model simulations. We also excluded measurements of ice density in the Greenland ice sheet ablation zone from Cooper et al. (2018), as our focus is 
on snow and firn density. Three profiles where MAR v3.2 predicted subsurface ice in the percolation zone (likely due to initialization errors) were also excluded from the comparison with MAR v3.2. We add one density profile not included in the 2018 SUMup dataset collected in 2010 at the Greenland ice sheet Summit camp (Tedesco and Marshall, 2019). The profiles examined here consist of 522 unique profiles collected at 417 locations (Figure 1a).

2.3 Data processing and methods of comparison

We compared observed profiles from SUMup with coincident profiles in space and time from MAR. All except one measurement location (ETH camp in the ablation zone; Ohmura 1991, 1992; Lefebre et al., 2003) fall into areas of net accumulation as defined by MAR average SMB for September 1983 through August 2017. Areas of net positive SMB were subdivided into relatively "wet" and relatively "dry" areas based on the average number of melt days. A melt day was defined as a day in which meltwater production exceeded $8.25 \mathrm{~mm}$ water equivalent per day (e.g. Fettweis et al., 2011). The number of days of melting varies smoothly across the GrIS, so we chose a somewhat arbitrary threshold of 5 melt days to define "wet" vs. "dry" areas. This threshold is approximately the median between the median number of annual melt days for a given 
model pixel (1.4) and the average (14.6 days), and divides the distribution of average melt days between the upper $37^{\text {th }}$ and lower $63^{\text {rd }}$ percentiles. Figure 1a shows the average 1983 through 2017 MAR SMB, along with all SUMup points used in this study (consisting of 522 profiles), with colors indicating different divisions of profiles.

To compare MAR with SUMup, we computed average depth-density profiles by extracting the average value (and standard deviation) across all profiles and separated into 96 wet and 323 dry profiles, and 103 profiles from the ETH camp site. We do not include ETH camp in the compilation of "wet" profiles because it includes a seasonal snowpack and subsurface ice, but find it useful to examine given its unique location and multiple measurements collected over two seasons. Modeled values are excluded at depths where there are missing observations. We also compute average values over fixed depth ranges (top $1 \mathrm{~m}, 1-10 \mathrm{~m}$ ) for models and observations, only considering locations where data are available over $90 \%$ of the depth range. We constrain our analysis to the top $10 \mathrm{~m}$ of snow and firn as the majority of SUMup profiles do not extend below this depth.

\section{Observed vs. Modeled Density Profiles}

A comparison between MAR and observed density profiles from SUMup is shown in Figure

1. The averaged observations span multiple years, seasons, and measurement types. The goal is not to establish an ice-sheet wide "standard" density profile, but to identify systematic biases in modeled density.

Within the relatively dry regions of the ice sheet (Figure 1b, Table 1), MAR captures the average profile and the range of variability between profiles very well between 1 and $10 \mathrm{~m}$ in depth (with a bias of $-0.013 \pm 0.046 \mathrm{~g} / \mathrm{cm}^{3}$ ), but underestimates density within the top $1 \mathrm{~m}$ (by $\left.-0.063 \pm 0.042 \mathrm{~g} / \mathrm{cm}^{3}\right)$. The standard deviation for modeled and observed profiles is also quite low $\left(\sim 0.030 \mathrm{~g} / \mathrm{cm}^{3}\right.$ for observed profiles and $\sim 0.020$ to $0.030 \mathrm{~g} / \mathrm{cm}^{3}$ for model profiles;

Table 1), indicating a fairly low variability in time and space in dry areas. The negative biases in the top $1 \mathrm{~m}$ are likely associated with dry snow processes, in particular the initial fresh snow density (Fausto et al., 2018), as discussed further in Section 4.

In wetter regions of the ice sheet, there is larger variability between profiles, as indicated by the large standard deviation for both MAR and SUMup at all depths (Figure 1c, Table 1). This likely results from intermittent rapid densification due to meltwater retention and refreezing. MAR also underestimates near-surface density within the top $1 \mathrm{~m}$ in wet areas (by $-0.029 \pm 0.098 \mathrm{~g} / \mathrm{cm}^{3}$ ), but the uncertainty associated with variability between profiles is 
larger than the bias. For wet areas between 1 and 10 meters in depth, MAR tends to slightly overestimate density on average (by $+0.057 \pm 0.069 \mathrm{~g} / \mathrm{cm}^{3}$ ) although the bias is still within the uncertainty range. At the ETH camp location, MAR also tends to overestimate density within the top $1 \mathrm{~m}$ (by $0.118 \pm 0.117 \mathrm{~g} / \mathrm{cm}^{3}$, Table 1 , Figure $\mathrm{S} 1$ ). This is likely a result of high melt and meltwater refreezing in MAR, which produce a snowpack that is both too shallow and too dense (Figure S1).

The negative bias from MAR relative to SUMup in the top $1 \mathrm{~m}$ persists across most of the ice sheet, with the exception of positive biases below $2000 \mathrm{~m}$ in elevation along the western ice sheet margin (Fig. 2a). A scatter plot of MAR vs. observed average values in the top $1 \mathrm{~m}$ (Fig 2c) also indicates that the MAR bias is consistently negative for low-density values (corresponding with dry areas) but becomes positive for higher density values. An analysis of top $1 \mathrm{~m}$ biases according to time of year (Figure S2a) indicates that the positive MAR biases occur primarily in the summer months of June and July in melt areas and at ETH camp (with an average June and July bias of $+0.133 \pm 0.095 \mathrm{~g} / \mathrm{cm}^{3}$ ). At ETH camp, the bias also tends to increase over the course of the season. At this location, MAR underestimates snow depth (Figure S3a). The top $1 \mathrm{~m}$ density bias at ETH camp therefore partly results from the presence of ice within the top $1 \mathrm{~m}$ in MAR, in addition to overestimated MAR snow density (Figure S3b). In contrast, for measurements taken during April and May at both ETH camp and other "wet" locations, MAR exhibits a negative bias $\left(-0.070 \pm 0.063 \mathrm{~g} / \mathrm{cm}^{3}\right)$ as snowpack density in the $1^{\text {st }}$ meter in these areas mainly results from fresh snow accumulation in winter, and has not yet experienced summer melt and refreezing.

The collective evidence indicates that positive MAR biases in the top $1 \mathrm{~m}$ occur in areas of melt, retention and refreezing during summer months, and are therefore associated with melt processes. The positive biases in the top $1 \mathrm{~m}$ are also generally associated with higher amounts of refreezing over the time period that the top $1 \mathrm{~m}$ is deposited (Figure $\mathrm{S} 2 \mathrm{~b}$ ). Contributing factors could include overestimation of melt, thermodynamic processes contributing to too much refreezing, or overestimated liquid water retention. The value of the irreducible water saturation in MAR is relatively high (7-10\%) compared to the RACMO2.3p2 RCM (Noël et al., 2018) (1\%), and could potentially lead to overestimated liquid water retention. 
Between 1 and $10 \mathrm{~m}$ in depth, biases cluster regionally (Fig. 2a), with MAR overestimating density in low elevation areas and in northeast Greenland, and underestimating density elsewhere. The positive biases in low elevation areas are likely due to the same processes contributing to positive biases in the top $1 \mathrm{~m}$; they are generally associated with higher refreezing rates (Fig. S2c). The positive bias in northeast Greenland is likely related to a low accumulation rate (of below $\sim 15 \mathrm{~cm}$ water equivalent per year) in this area. Indeed, a lower accumulation rate tends to produce a larger 1 to $10 \mathrm{~m}$ density bias for "dry" snow areas (Figure S2d). In "wet" areas there is no clear relationship likely due to the influence of meltwater processes. In the dry, low accumulation areas with less than $15 \mathrm{~cm}$ water equivalent accumulation, the MAR simulation spin-up time of 5 years is inadequate for completely refreshing the snowpack. In fact, more than 60 years of spin-up time are required to fully refresh the snowpack in these areas (Figure S4). Therefore, density profile biases below $1 \mathrm{~m}$ in low-accumulation areas likely originate from the initial prescribed snow density profile, rather than accumulated snowfall.

\section{Modeled Density Profile Sensitivity}

To better understand the sensitivity of MAR-simulated density to atmospheric parameters, spatial resolution and physical assumptions, we evaluated simulated profiles from multiple MAR simulations featuring different spatial resolutions, reanalysis forcing and parameterizations. This gives an indication of the controls on model-simulated GrIS density.

Simulated profiles from different MAR versions (v3.9.3, v3.5.2, and v3.2) are shown in Figure 3. Results from MAR v3.9.3 run at different spatial resolutions $(7.5,15,20$, and 25 $\mathrm{km}$ ), all forced with the ERA-Interim reanalysis, and a $20 \mathrm{~km}$ spatial resolution simulation with MAR v3.9.3 forced with the NCEP-NCAR reanalysis, are shown in Figure S5. In both wet and dry areas, changing the spatial resolution in MAR v3.9.3 produced little difference in the average density profiles at SUMup sites (Fig S5 a,b; Table S1). Forcing MAR v3.9.3 with different reanalysis products (ERA-Interim vs. the NCEP-NCAR reanalysis) also had a minor impact on average profiles (Fig. S5 c,d; Table S1). At the ETH camp location, changing the spatial resolution did have an impact on density profiles (Fig. S6; Table S1), likely due to the effect of spatial resolution on grid box elevation. The grid box containing ETH camp is about $100 \mathrm{~m}$ higher in elevation for the $25 \mathrm{~km}$ resolution simulation compared 
with the $7.5 \mathrm{~km}$ resolution simulation, leading to colder temperatures, less melt and refreezing and lower density values.

Overall, the largest differences in model profiles result from differences in model version (Fig. 3; Table S2), in particular between MAR v3.2 and the other model versions, due to the different assumptions and initialization methods. The differences between MAR v3.9.3 and v3.5.2 are small, as there are no differences in initialization or fresh snow density between the simulations. The two models do differ in the representation of irreducible water content (10\% in MAR v3.9 vs. $7 \%$ for MAR v3.5.2), which suggests that the 3\% difference in this value does not have a large impact on the average profiles. Close to the surface, MAR v3.2 density values are lower than the other model versions (Figure 3, Table S2). This results from a lower initial fresh snow density in MAR v3.2 compared with the other versions $(0.05$ $\mathrm{g} / \mathrm{cm}^{3}$ vs. $0.2 \mathrm{~g} / \mathrm{cm}^{3}$ ), confirming the importance of this factor. Between 1 and $10 \mathrm{~m}$ in depth MAR v3.2 density values are higher than other model versions for both wet and dry areas. The source of these differences is not entirely clear. One possibility is differences in snowpack initialization. For each year of outputs from MAR, the snow profile is initialized with an earlier simulation and spun up over a 5-year period. MAR v3.9 and v3.5.2 are initialized with profiles from an older version of MAR (v3.4), while MAR v3.2 is initialized with a much earlier version of MAR (v1.0). Another possibility is that the very low-density layers near the surface in MAR v3.2 allow for excess meltwater retention and small melt events can lead to accumulated refrozen melt over time. Further sensitivity studies are needed to determine the causes of these differences.

\section{Conclusions}

Our results point to several factors that can introduce biases in simulated GrIS snow density profiles, leading to errors in estimated surface mass balance, from both remote sensing measurements of GrIS accumulation (e.g. Koenig et al., 2016), and from climate model estimates of liquid water retention and refreezing. These include (1) errors in near surface density values resulting from errors in the parameterized density of freshly fallen snow, (2) errors in surface and subsurface density in areas of high melt, liquid water retention and refreezing, and (3) errors associated with model initialization, especially in locations of low accumulation, where a lengthy model spin-up time may be required to properly initialize the snowpack. 
Specifically, we find that in the MAR regional climate model, density within the top $1 \mathrm{~m}$ of snow is underestimated by $10 \%$. This translates to an error of roughly $36 \mathrm{Gt}$, or $10 \%$ of annual average SMB derived from snow accumulation thickness in "dry snow" areas (Text S2, Supplementary information). The near-surface density value is highly sensitive to the choice of the initial freshly fallen snow density, and suggests that the fresh snow density simulated by MAR (a function of temperature and wind speed) is too low on average. Adjustments to the minimum fresh snow density in MAR v3.5.2 and v3.9 improved the agreement with observations, while still producing a systematic bias near the surface. These results are consistent with the study of Fausto et al. (2018), who found that a fresh snow density of $0.315 \mathrm{~g} \mathrm{~cm}^{-3}$ was a better choice for estimating near-surface density than estimates from model parameterizations. When combining snow and firn model density estimates with remote sensing-derived thickness change measurements, care should be taken to verify the accuracy of near-surface density values, and the values should be corrected using observations (as done by Koenig et al., 2016). Adjustments to the minimum initial falling snow density (e.g. as done by Agosta et al., 2019 for MAR over Antarctica), are likely sufficient to improve agreement with observations.

We found an overestimation of sub-surface density values (by $\sim 10 \%$ ) in areas with greater than 5 days of melt per year in MAR. If extended across the "relatively wet" areas over the ice sheet, the density bias between 1 and $10 \mathrm{~m}$ translates to an average underestimate of 223 Gt on average ( $50 \%$ of 1980-1999 annual average SMB; Text S2, Supplementary information), although the variability in density values leads to an uncertainty of $270 \mathrm{Gt}$. A similar overestimation was found in the IMAU-FDM firn model of Ligtenberg et al. (2018), which is forced by the RACMO2.3 RCM (Noël et al., 2018). The IMAU-FDM tended to underestimate firn air content (i.e. overestimate snow density) as a result of an apparent overestimation of melt from RACMO2.3. Reduced melt in the latest RACMO2.3p2 version substantially reduced the observed biases (Ligtenberg et al., 2018). The cause of the bias could be similar in the case of MAR. It is also possible that the relatively high irreducible water saturation from MAR (10\% vs. $1 \%$ in RACMO) contributes to overestimated liquid water retention and refreezing. This factor was found to influence SMB and snow temperature profiles in the HIRHAM5 RCM (Langen et al., 2017), though the effects were smaller than melt-albedo effects. Further research is required to better understand the impact of meltwater production rate vs. parameterization of meltwater retention and refreezing in models simulating snow and firn density, given the potentially large impact on estimated SMB. 
We find that in areas of low accumulation rate, the model spin-up time can also contribute to subsurface density biases. In areas of low accumulation (below $15 \mathrm{~cm}$ w.e. per year), the MAR snowpack has likely not been spun up for a sufficient length of time to completely refresh the snowpack, leading to positive biases in simulated density. For these low accumulation areas, an offline spin-up of a standalone snowpack model is necessary (as is done for the standalone IMAU-FDM model of Ligtenberg et al., 2011, 2018) and can help to improve the model accuracy.

Finally, additional measurements and model evaluation are required in the GrIS ablation zone, where errors in snow depth over ice can further complicate calculations of mass from elevation change as well as estimates of liquid water retention and refreezing.

\section{Acknowledgments, Samples, and Data}

The authors thank Lynn Montgomery for assistance with processing and interpreting the SUMup dataset, and Shujie Wang for suggestions regarding text and figures. We also thank the editor and several anonymous reviewers for helpful comments and suggestions. P.A. and M.T. acknowledge support from the NASA Cryosphere program (NNX17AH04G). P.A. was also supported by an appointment to the NASA Postdoctoral Program (NPP) at the NASA Goddard Institute for Space Studies, administered by the Universities Space Research Organization and Oak Ridge Associated Universities under contract with NASA. MAR v3.5.2 outputs are available at ftp://ftp.climato.be/fettweis/MARv3.5/. MAR v3.9.3 outputs (for density and SMB) are available at ftp://ftp.climato.be/fettweis/.MARv3.9.3. MAR v3.2 outputs are available from the Arctic Data Center (doi: 10.5065/D6JH3J7Z). MAR source code is available at ftp://ftp.climato.be/fettweis/MARv3.5/.src and $\mathrm{ftp} / / / \mathrm{ftp} . c l i m a t o . b e / f e t t w e i s / M A R v 3.9 / . s r c$ and $\mathrm{ftp}$ //ftp.climato.be/fettweis/.MARv3.2/MARv3.2-2013-08-01.tgz. The SUMup dataset (2018 release) is publicly available from the Arctic Data Center (doi: 10.18739/A2JH3D23R). An additional density profile taken at the Greenland ice sheet Summit camp in 2010 is also available from the Arctic Data Center (doi: 10.18739/A2M03XX3M). This dataset has also been included in the 2019 SUMup dataset (Koenig and Montgomery, 2019; doi: 10.18739/A26D5PB2S). 


\section{References}

Agosta, C., Amory, C., Kittel, C., Orsi, A., Favier, V., Gallée, H., et al. (2019) Estimation of the Antarctic surface mass balance using the regional climate model MAR (1979-2015) and identification of dominant processes. The Cryosphere, 13, 281-296, https://doi.org/10.5194/tc-13-281-2019.

Alley, R. B. (1999) GISP2 Stratigraphy, PANGAEA, https://doi.org/10.5194/PANGAEA.56103.

Alexander, P., Tedesco, M., Fettweis, X., van de Wal, R. S. W., Smeets, C. J. P. P., and van den Broeke, M. R. (2014) Assessing spatio-temporal variability and trends in modelled and measured Greenland Ice Sheet albedo (2000-2013). The Cryosphere, 8, 2293-2312, https://doi.org/10.5194/tc-8-2293-2014.

Arthern, R. J., Vaughan, D. G., Rankin, A. M., Mulvaney, R., \& Thomas, E. R. (2010) In situ measurements of Antarctic snow compaction compared with predictions of models. Journal of Geophysical Research, 115, F03011, https://doi.org/10.1029/2009JF001306.

Baker, I. (2016) NEEM firn core 2009S2 density and permeability, Arctic Data Center, https://doi.org/10.18739/A2Q88G.

Benson, C. (2013) Greenland snow pit and core stratigraphy (analog and digital formats), National Snow and Ice Data Center, Boulder, Colorado, USA.

Benson, C. S. (2017) Greenland snow pit and core stratigraphy, Carl S. Benson Collection, Coll. 2010011, Roger G. Barry Archives and Resource Center, National Snow and Ice Data Center, Boulder, Colorado, USA.

Bolzan, J. F., \& Strobel, M. (1999a) Oxygen isotope data from snowpit at GISP2 Site 13, PANGAEA, https://doi.org/10.5194/PANGAEA.55510.

Bolzan, J. F., \& Strobel, M. (1999b) Oxygen isotope data from snowpit at GISP2 Site 15, PANGAEA, https://doi.org/10.5194/PANGAEA.55511.

Bolzan, J. F., \& Strobel, M. (1999c) Oxygen isotope data from snowpit at GISP2 Site 31, PANGAEA, https://doi.org/10.5194/PANGAEA.55512.

Bolzan, J. F., \& Strobel, M. (1999d) Oxygen isotope data from snowpit at GISP2 Site 37, PANGAEA, https://doi.org/10.5194/PANGAEA.55513.

Bolzan, J. F., \& Strobel, M. (1999e) Oxygen isotope data from snowpit at GISP2 Site 51, PANGAEA, https://doi.org/10.5194/PANGAEA.55514.

Bolzan, J. F., \& Strobel, M. (1999f) Oxygen isotope data from snowpit at GISP2 Site 57, PANGAEA, https://doi.org/10.5194/PANGAEA.55515.

Bolzan, J. F., \& Strobel, M. (1999g) Oxygen isotope data from snowpit at GISP2 Site 73, PANGAEA, https://doi.org/10.5194/PANGAEA.55516.

Bolzan, J. F., \& Strobel, M. (2001a) Oxygen isotope data from snowpit at GISP2 Site 44, PANGAEA, https://doi.org/10.5194/PANGAEA.59995.

Bolzan, J. F., \& Strobel, M. (2001b) Oxygen isotope data from snowpit at GISP2 Site 571, PANGAEA, https://doi.org/10.5194/PANGAEA.59996.

Brun, E., Martin, E., Simon, V., Gendre, C., \& Coleou, C. (1989) An energy and mass model of snow cover suitable for operational avalanche forecasting. Journal of Glaciology, 35, 121, 333- 342 . 
Brun, E., David, P., Sudul, M., \& Brunot, G. (1992) A numerical model to simulate snowcover stratigraphy for operational avalanche forecasting. Journal of Glaciology, 38, 128, 1322.

Chellman, N. (2016) Core atmospheric and snow measurements at Summit Greenland Environmental Observatory: Snow pit. Arctic Data Center, https://doi.org/10.18739/A2888F.

Colgan, W., Box, J. E., Andersen, M. L., Fettweis, X., Csathó, B., Fausto, R. S., van As, D., \& Wahr, J. (2015) Greenland high-elevation mass balance: inference and implication of reference period (1961-90) imbalance. Annals of Glaciology, 56, 70, 105-117, https://doi.org/10.3189/2015AoG0A967.

Conway, H. (2003) Roosevelt Island ice core density and beta count data. U. S. Antarctic Program Data Center, https://doi.org/10.7265/N55718ZW.

Cooper, M. G., Smith, L. C., Rennermalm, A. K., Pitcher, L., Ryan, J. C., Yang, K., and Cooley, S. W. (2018) Direct measurements of ice density down to $1 \mathrm{~m}$ depth in the Greenland ice sheet ablation zone during July 2016 from shallow ice cores, In supplement to: Cooper, M. G. et al. (2018) Meltwater storage in low-density near-surface bare ice in the Greenland ice sheet ablation zone. The Cryosphere, 12, 955-970, https://doi.org/10.5194/tc-12-9552018, https://doi.org/10.5194/PANGAEA.886747.

Dee, D. P., Uppala, S. M., Simmons, A. J., Berrisford, P., Poli, P., Kobayashi, S., et al. (2011) The ERA-Interim reanalysis: configuration and performance of the data assimilation system. Quarterly Journal of the Royal Meteorological Society, 137, 553-597, https://doi.org/10.1002/qj.828.

DeRidder, K. \& Shayes, G. (1997) The IAGL land surface model. Journal of Applied Meteorology, 36, 167-182.

Dibb, J. E. \& Fahnestock, M. (2004) Snow accumulation, surface height change, and firn densification at Summit, Greenland: Insights from 2 years of in situ observations. Journal of Geophysical Research, 109, D24113, https://doi.org/10.1029/2003JD004300.

Dibb, J. E., Whitlow, S. I., \& Arsenault, M. (2007) Seasonal variations in the soluble ion content of snow at Summit, Greenland: Constraints from three years of daily surface snow samples, Atmospheric Environment, 41, 5007-5019, https://doi.org/10.1016/j.atmosenv.2006.12.010.

Fausto, R. S., Box, J. E., Vandecrux, B., van As, D., Steffen, K., MacFerrin, M. J., Machguth, H., Colgan, W., Koenig, L. S., McGrath, D., Charalampidis, C., \& Braithwaite, R. J. (2018) A snow density dataset for improving surface boundary conditions in Greenland ice sheet firn modeling. Frontiers in Earth Science, 6, https://doi.org/10.3389/feart.2018.00051.

Fettweis, X., Tedesco, M., van den Broeke, M. R., \& Ettema, J. (2011) Melting trends over the Greenland ice sheet (1958-2009) from spaceborne microwave data and regional climate models. The Cryosphere, 5, 359-375, https://doi.org/10.5194/tc-5-359-2011.

Fettweis, X., Box, J. E., Agosta, C., Amory, C., Kittel, C., Lang, C., et al. (2017) Reconstructions of the 1900-2015 Greenland ice sheet surface mass balance using the regional climate MAR model. The Cryosphere, 11, 1015-1033, https://doi.org/10.5194/tc-111015-2017.

Forster, R. R., Box, J. E., van den Broeke, M. R., Miège, C., Burgess, E. W., van Angelen, J. H., et al. (2013) Extensive liquid meltwater storage in firn within the Greenland ice sheet. Nature Geoscience, 7, 95-98, https://doi.org/10.1038/ngeo2043. 
Fréville, H., Brun, E., Picard, G., Tatarinova, N., Arnaud, L., Lanconelli, C., et al. (2014) Using MODIS land surface temperatures and the Crocus snow model to understand the warm bias of ERA-Interim reanalyses at the surface in Antarctica. The Cryosphere, 8, 1361-1373, https://doi.org/10.5194/tc-8-1361-2014.

Gallée, H. \& Shayes, G. (1994) Development of a three-dimensional meso- $\gamma$ primitive equation model: katabatic winds simulation in the area of Terra Nova Bay, Antarctica. Monthly Weather Review, 122, 671-685.

Hawley, R. L., Courville, Z. R., Kerl, L. M., Lutz, E. R., Osterberg, E. C., Overly, T. B., and Wong, G. J. (2014) Recent accumulation variability in northwest Greenland from groundpenetrating radar and shallow cores along the Greenland Inland Traverse. Journal of Glaciology, 60, 375-382, https://doi.org/10.3189/2014JoG13J141.

Harper, J., Humphrey, N., Pfeffer, W. T., Brown, J., \& Fettweis, X. (2012) Greenland icesheet contribution to sea-level rise buffered by meltwater storage in firn. Nature, 491, 240243, https://doi.org/10.1038/nature11566.

Helm, V., Humbert, A., and Miller, H. (2014) Elevation and elevation change of Greenland and Antarctica derived from CryoSat-2. The Cryosphere, 8, 1539-1559, https://doi.org/10.5194/tc-8-1539-2014.

Kalnay, E., Kanamitsu, M., Kistler, R., Collins, W., Deaven, D., Gandin, L., et al. (1996) The NCEP-NCAR 40 year reanalysis project. Bulletin of the American Metorological Society, 77, 437-471.

Koenig, L. \& Montgomery, L. (2018) Surface mass balance and snow depth on sea ice working group (SUMup) snow density subdataset, Greenland and Antarctica, 1950-2018. Arctic Data Center. https://doi.org/10.18739/A2JH3D23R.

Koenig, L. \& Montgomery, L. (2019) Surface mass balance and snow depth on sea ice working group (SUMup) snow density subdataset, Greenland and Antarctica, 1950-2018. Arctic Data Center. https://doi.org/10.18739/A26D5PB2S.

Koenig, L. S., Miège, C., Forster, R. R., \& Brucker, L. (2014) Initial in situ measurements of perennial meltwater storage in the Greenland firn aquifer. Geophysical Research Letters, 41, 81-85, https://doi.org/10.1002/2013GL058083.

Koenig, L. S., Ivanoff, A., Alexander, P. M., MacGregor, J. A., Fettweis, X., Panzer, B., et al. (2016) Annual Greenland accumulation rates (2009-2012) from airborne snow radar. The Cryosphere, 10, 1739-1752, https://doi.org/10.5194/tc-10-1739-2016.

Kojima, K. (1954) Viscoelastic properties of snow. Low Temperature Science, A12, 1-13.

Kojima, K. (1967) Densification of seasonal snow cover. The Physics of Snow and Ice: Proceedings 雪头の物理学: 論文集, $1,2,929-952$.

Kuipers Munneke, P., Ligtenberg, S. R. M., Noël, B. P. Y., Howat, I. M., Box, J. E., MosleyThompson, E., et al. (2015) Elevation change of the Greenland Ice Sheet due to surface mass balance and firn processes, 1960-2014. The Cryosphere, 9, 2009-2025, https://doi.org/10.5194/tc-9-2009-2015.

Langen, P. L., Fausto, R. S., Vandecrux, B., Mottram, R. H., and Box, J. E. (2017) Liquid water flow and retention on the Greenland ice sheet in the regional climate model HIRHAM5: local and large-scale impacts. Frontiers in Earth Science, 4, https://doi.org/10.3389/feart.2016.00110.

Lefebre, F., Gallée, H., van Ypersele, J.-P., \& Greuell, W. (2003) Modeling of snow and ice 
melt at ETH Camp (West Greenland): A study of surface albedo. Journal of Geophysical Research, 108, D8, 4231, https://doi.org/10.1029/2001JD001160.

Lenaerts, J. T. M., van den Broeke, M. R., Déry, S. J., van Meijgaard, E., van de Berg, W. J., Palm, S. P., \& Sanz Rodrigo, J. (2012) Modeling drifting snow in Antarctica with a regional climate model: 1. Methods and model evaluation. Journal of Geophysical Research, 117, D05108, https://doi.org/10.1029/2011JD016145.

Li, J. \& Zwally, H. J. (2011) Modeling of firn compaction for estimating ice-sheet mass change from observed ice-sheet elevation change. Annals of Glaciology, 52, 59, 1-7, https://doi.org/10.3189/172756411799096321.

Ligtenberg, S. R. M., Helsen, M. M., \& van den Broeke, M. R. (2011) An improved semiempirical model for the densification of Antarctic firn. The Cryosphere, 5, 809-819, https://doi.org/10.5194/tc-5-809-2011.

Ligtenberg, S. R. M., Kuipers Munneke, P., Noël, B. P. Y., and van den Broeke, M. R. (2018) Brief communication: Improved simulation of the present-day Greenland firn layer (19602016). The Cryosphere, 12, 1643-1649, https://doi.org/10.5194/tc-12-1643-2018.

Machguth, H., MacFerrin, M. van As, D., Box, J. E., Charalampidis, C., Colgan, W., et al. (2016) Greenland meltwater storage in firn limited by near-surface ice formation. Nature Climate Change, 6, 390-393, https://doi.org/10.1038/NCLIMATE2899.

Markus, T., Nuemann, T., Martino, A., Abdalati, W., Brunt, K., Csatho, B., et al. (2017) The Ice, Cloud, and land Elevation Satellite-2 (ICESat-2): Science requirements, concept, and implementation. Remote Sensing of Environment, 190, 260-273,

https://doi.org/10.1016/j.rse.2016.12.029.

Mayewski, P., \& Whitlow, S. (2009a) Regional survey of Greenland, 1988 - snow pit data, Version 1.0, https://doi.org/10.5065/D6154F6J.

Mayewski, P., \& Whitlow, S. (2009b) Regional survey of Greenland, 1984, Version 1.0, https://doi.org/10.5065/D6S180MH.

Mayewski, P., \& Whitlow, S. (2009c) Snow pit data from Greenland Summit, 1987, Version 1.0, https://doi.org/10.5065/D63X84RQ.

Mayewski, P., \& Whitlow, S. (2009d) Snow pit data from Greenland Summit, 1989 to 1993, Version 1.0, https://doi.org/10.5065/D6NP22KX.

Medley, B., Joughin, I., Das, S. B., Steig, E. J., Conway, H., Gognineni, S., et al. (2013) Airborne-radar and ice-core observations of annual snow accumulation over Thwaites Glacier, West Antarctica confirm the spatiotemporal variability of global and regional atmospheric models. Geophysical Research Letters, 40, 3649-3654, https://doi.org/10.1002/grl.50706.

Miège, C., Forster, R. R., Box, J. E., Burgess, E. W., McConnell, J. R., Pasteris, D. R., and Spikes, V. B. (2013) Southeast Greenland high accumulation rates derived from firn cores and ground-penetrating radar. Annals of Glaciology, 54, 322-332, https://doi.org/10.3189/2013AoG63A358.

Miller, H., \& Schwager, M. (2000a) Density of ice core ngt37C95.2 from the North Greenland Traverse, PANGAEA, https://doi.org/10.5194/PANGAEA.57798.

Miller, H., \& Schwager, M. (2000b) Density of ice core ngt42C95.2 from the North Greenland Travers, PANGAEA, https://doi.org/10.5194/PANGAEA.57655.

Montgomery, L., Koenig, L., \& Alexander, P. (2018) The SUMup dataset: compiled 
measurements of surface mass balance components over ice sheets and sea ice with analysis over Greenland. Earth System Science Data, 10, 1959-1985, https://doi.org/10.5194/essd-10$1959-2018$

Mosley-Thompson, E., McConnell, J. R., Bales, R. C., Li, Z., Lin, P.-N., Steffen, K., Thompson, L. G., Edwards, R., \& Bathke, D. (2001) Local to regional-scale variability of annual net accumulation on the Greenland ice sheet from PARCA cores, Journal of Geophysical Research, 106, 33839-33851, https://doi.org/10.1029/2001JD900067.

Mouginot, J., Rignot, E., Bjørk, A. A., van den Broeke, M., Millan, R., Morlighem, M., Noël, B., Scheuchl, B., and Wood, M. (2019) Forty-six years of Greenland Ice Sheet mass balance from 1972 to 2018. Proceedings of the National Academy of Sciences, 116, 9239-9244, https://doi.org/10.1073/pnas.1904242116.

Navarre, J. P. (1975) Modèle unidimensionnel d'évolution de la neige déposée. Modéle perce-neige. Météorologie, 4, 3, 103-120.

Noël, B., van de Berg, W. J., Lhermitte, S., Wouters, B., Machguth, H., Howat, I., et al. (2017) A tipping point in refreezing accelerates mass loss of Greenland's glaciers and ice caps. Nature Communications, 8, 14730, https://doi.org/10.1038/ncomms14730.

Noël, B., van de Berg, W. J., van Wessem, M., van Meijgaard, E., van As, D., Lenaerts, J. T. M., et al. (2018) Modelling the climate and surface mass balance of polar ice sheets using RACMO2 - Part 1: Greenland (1958-2016). The Cryosphere, 12, 811-831, https://doi.org/10.5194/tc-12-811-2018.

Ohmura, A. (1991) ETH Greenland Expedition I, progress report no. 1, April 1989 to February 1991, ETH Zürich, Department of Geography, Technical Report, 108 pp.

Ohmura, A. (1992) ETH Greenland Expedition II, April 1991 to October 1992, ETH Zürich, Department of Geography, Technical Report, 94 pp.

Renaud, A. (1959) Etude physiques et chimiques sur la glace de l'inlandsis du Groenland, Meddeleser om Groenland, 177, 100-107.

Schaller, C. F., Freitag, J., Kipfsuhl, S., Laepple, T., Steen-Larsen, H. C., \& Eisen, O. (2016) A representative density profile of the North Greenland snowpack. The Cryosphere, 10, 1991-2002, https://doi.org/10.5194/tc-10-1991-2016.

Schaller, C. F., Kipfstuhl, S., Steen-Larsen, H. C., Freitag, J., \& Eisen, O. (2017) Spatial variability of density stratigraphy and melt features for two polar snowpacks in Greenland and East Antarctica, PANGAEA, https://doi.org/PANGAEA.88403.

Shepherd, A., Ivins, E. R., A, G., Barletta, V. R., Bentley, M. J., Bettadpur, S., et al. (2012) A reconciled estimate of ice sheet mass balance. Science, 338, 1183-1189, https://doi.org/10.1126/science.1228102.

Smith, L. C., Yang, K., Pitcher, L. H., Overstreet, B. T., Chu, V. M., Rennermalm, Å. K., et al. (2017) Direct measurements of meltwater runoff on the Greenland ice sheet surface.

Proceedings of the National Academy of Sciences, 114, E10622-E10631, https://doi.org/10.1073/pnas.1707743114.

Tedesco, M., \& Marshall, H. P. (2019) Greenland Ice Sheet Summit Camp Snow Density, Grain Size, and Hardness Profiles, June 26-27, 2010. Arctic Data Center, https://doi.org/10.18739/A2M03XX3M.

Steger, C. R., Reijmer, C. H., van den Broeke, M. R., Wever, N., Forster, R. R., Koenig, L. S., et al. (2017) Firn meltwater retention on the Greenland ice sheet: a model comparison. 
Frontiers in Earth Science, 5, 3, https://doi.org/10.3389/teart.2017.00003.

Vandecrux, B., MacFerrin, M., Machguth, H., Colgan, W. T., van As, D., Heilig, A., et al. (2019) Firn data compilation reveals widespread decrease of firn air content in western Greenland, The Cryosphere, 13, 845-859, https://doi.org/10.5194/tc-13-845-2019.

Vionnet, V., Brun, E., Morin, S., Boone, A., Faroux, P., LeMoigne, P., Martin, E., \&

Wilhelms, F. (2000a) Density of ice core ngt03C93.2 from the North Greenland Traverse. PANGAEA, https://doi.org/10.1594/PANGAEA.56560.

Wilhelms, F. (2000b) Density of ice core ngt06C93.2 from the North Greenland Traverse. PANGAEA, https://doi.org/10.1594/PANGAEA.57153.

Wilhelms, F. (2000c) Density of ice core ngt14C93.2 from the North Greenland Traverse. PANGAEA, https://doi.org/10.1594/PANGAEA.56615.

Wilhelms, F. (2000d) Density of ice core ngt27C93.2 from the North Greenland Traverse. PANGAEA, https://doi.org/10.1594/PANGAEA.57296.

Zwally, H. J., Giovinetto, M. B., Li, J., Cornejo, H. G., Beckley, M. A., Brenner, A. C., Saba, J. L., \& Yi, D. (2005) Mass changes of the Greenland and Antarctic ice sheets and shelves and contributions to sea-level rise: 1992-2002. Journal of Glaciology, 51, 175, 509-527, https://doi.org/10.3189/172756505781829007.

Zwally, H. J., Li, J., Brenner, A. C., Beckley, M., Cornejo, H. G., DiMarzio, J., et al. (2011) Greenland ice sheet mass balance: distribution of increased mass loss with climate warming; 2003-07 versus 1992-2002. Journal of Glaciology, 57, 201, 88-102, https://doi.org/10.3189/002214311795306682. 
Table 1: Average and standard deviations of observed (SUMup) and modeled (MAR) density values (in $\mathrm{g} / \mathrm{cm}^{3}$ ) for different snow/firn pack depth ranges for all profiles and profile subsets. The "N" column indicates the sample size used for each category.

\begin{tabular}{cccccc}
\hline & & SUMup & MARv3.9 7.5 km & MAR - SUMup & $\mathrm{N}$ \\
\hline All Profiles & $0-1 \mathrm{~m}$ & $0.354 \pm 0.057$ & $0.320 \pm 0.125$ & $-0.034 \pm 0.090$ & 407 \\
& $1-10 \mathrm{~m}$ & $0.515 \pm 0.101$ & $0.541 \pm 0.140$ & $+0.026 \pm 0.069$ & 111 \\
\hline \multirow{2}{*}{ "Dry" Profiles } & $0-1 \mathrm{~m}$ & $0.331 \pm 0.035$ & $0.268 \pm 0.020$ & $-0.063 \pm 0.042$ & 293 \\
& $1-10 \mathrm{~m}$ & $0.442 \pm 0.029$ & $0.429 \pm 0.028$ & $-0.013 \pm 0.046$ & 49 \\
\hline \multirow{2}{*}{ "Wet" Profiles } & $0-1 \mathrm{~m}$ & $0.392 \pm 0.059$ & $0.362 \pm 0.120$ & $-0.029 \pm 0.098$ & 60 \\
& $1-10 \mathrm{~m}$ & $0.573 \pm 0.101$ & $0.630 \pm 0.129$ & $+0.057 \pm 0.069$ & 62 \\
\hline ETH Camp & $0-1 \mathrm{~m}$ & $0.439 \pm 0.052$ & $0.557 \pm 0.165$ & $+0.118 \pm 0.117$ & 54 \\
\hline
\end{tabular}



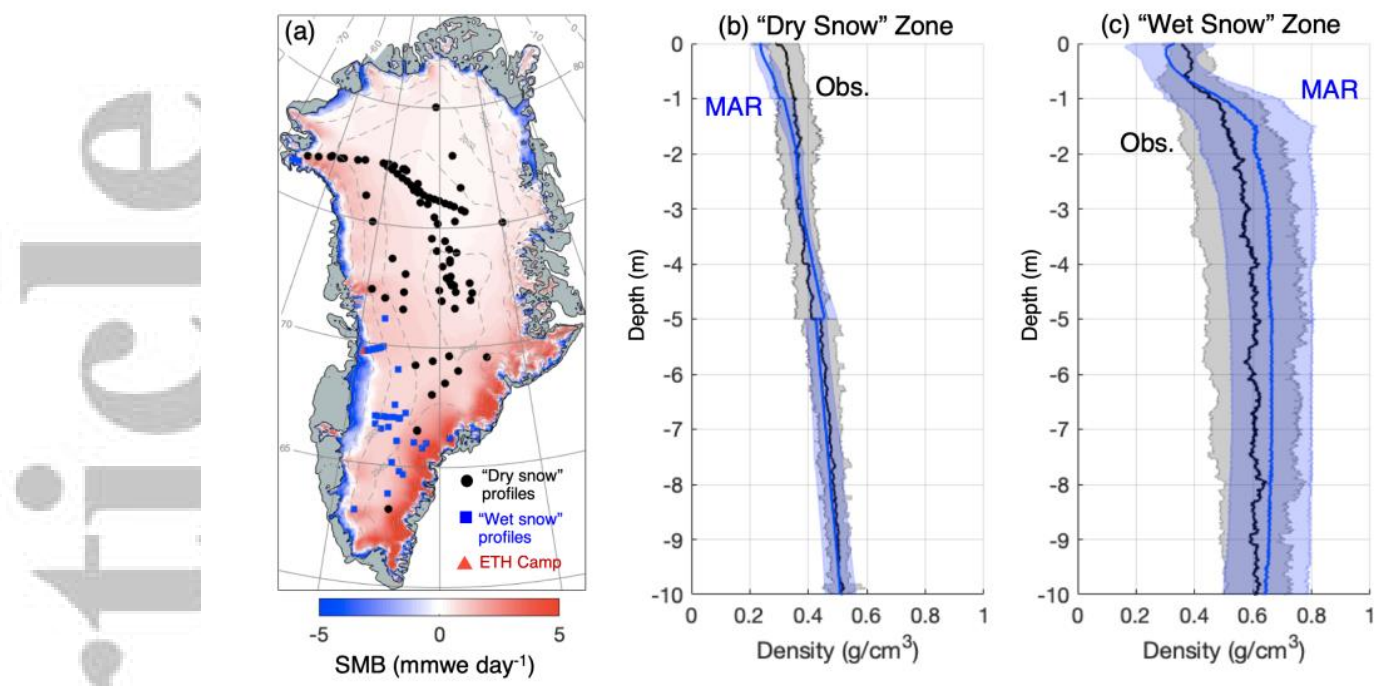

Figure 1: (a) MAR v3.9.3 average annual GrIS SMB for September 1983 through August 2017 (mm water equivalent per day), plotted with the location of SUMup density profiles. Red points are located in the mean ablation zone, blue points experience $>5$ days of melt per year, and black points exhibit $<5$ days per melt per year on average according to MAR. (b) Average observed and MAR v3.9.3 (7.5 km resolution) profiles for dry snow locations (c) Same as (b) for "wet snow" locations. Shading indicates one standard deviation for all measurement or model points at a given depth level.

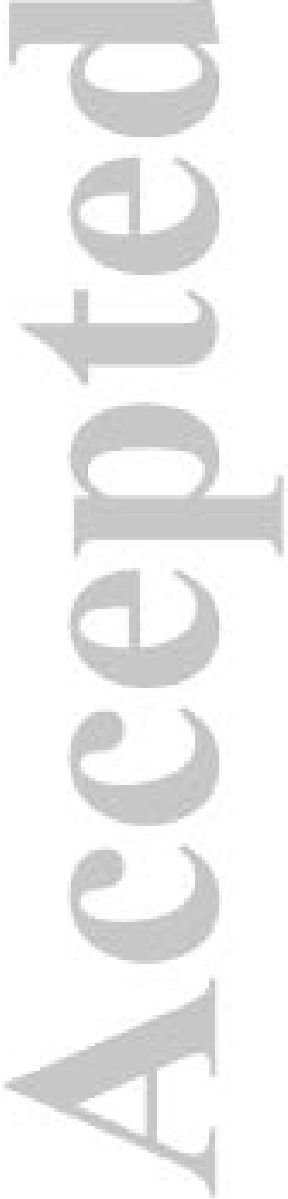




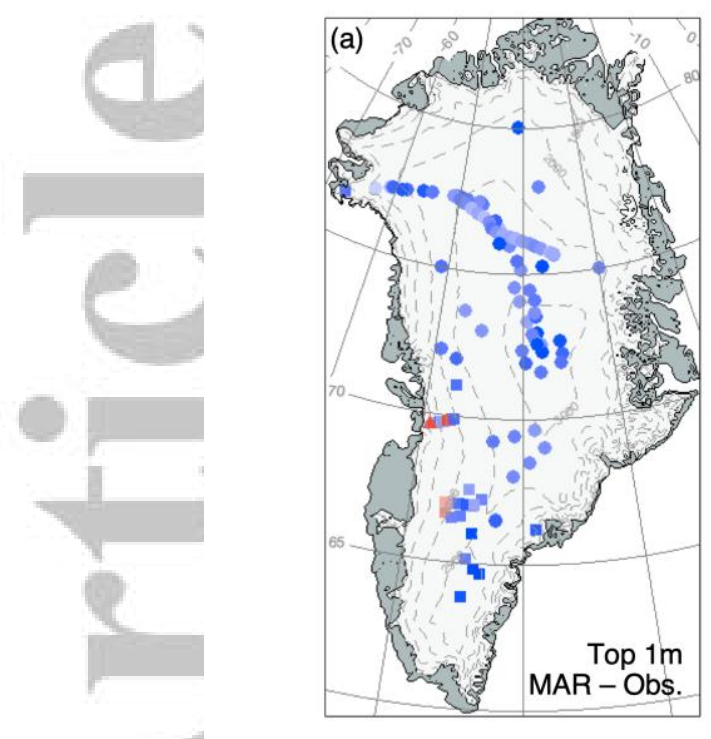

(c) Top 1m MAR vs. Obs.

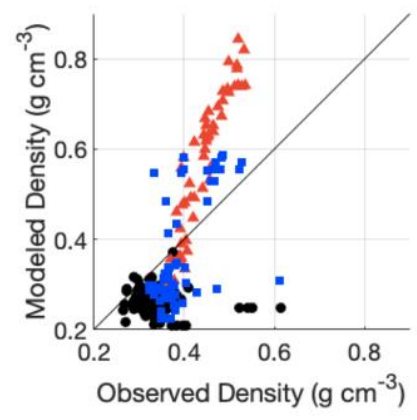

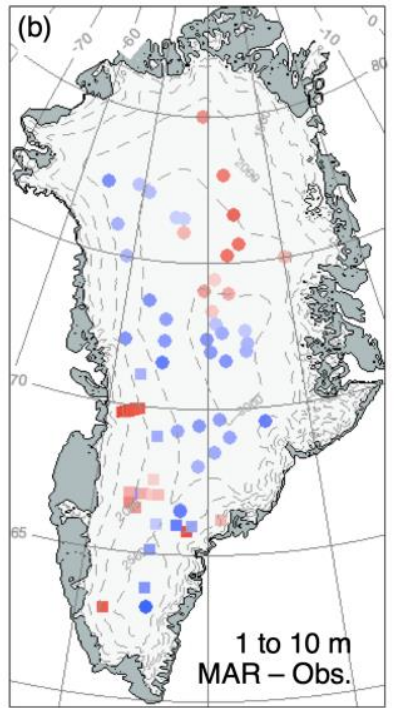

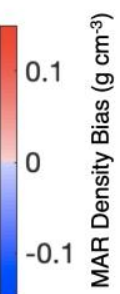

- "Dry snow"

- "Wet snow"
profiles

$\Delta$ ETH Camp

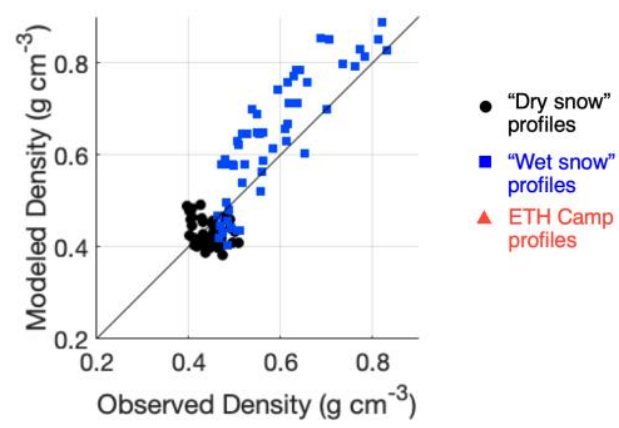

Figure 2: (a) Average density bias in the top $1 \mathrm{~m}$ of the snowpack (MAR v3.9.3 - observed values). (b) Same as (a) for 1 to 10 meters in depth. (c) Scatter plot of modeled vs. observed density in the top $1 \mathrm{~m}$, with different regions identified. (d) Same as (c) for the 1 to $10 \mathrm{~m}$ depth range. 

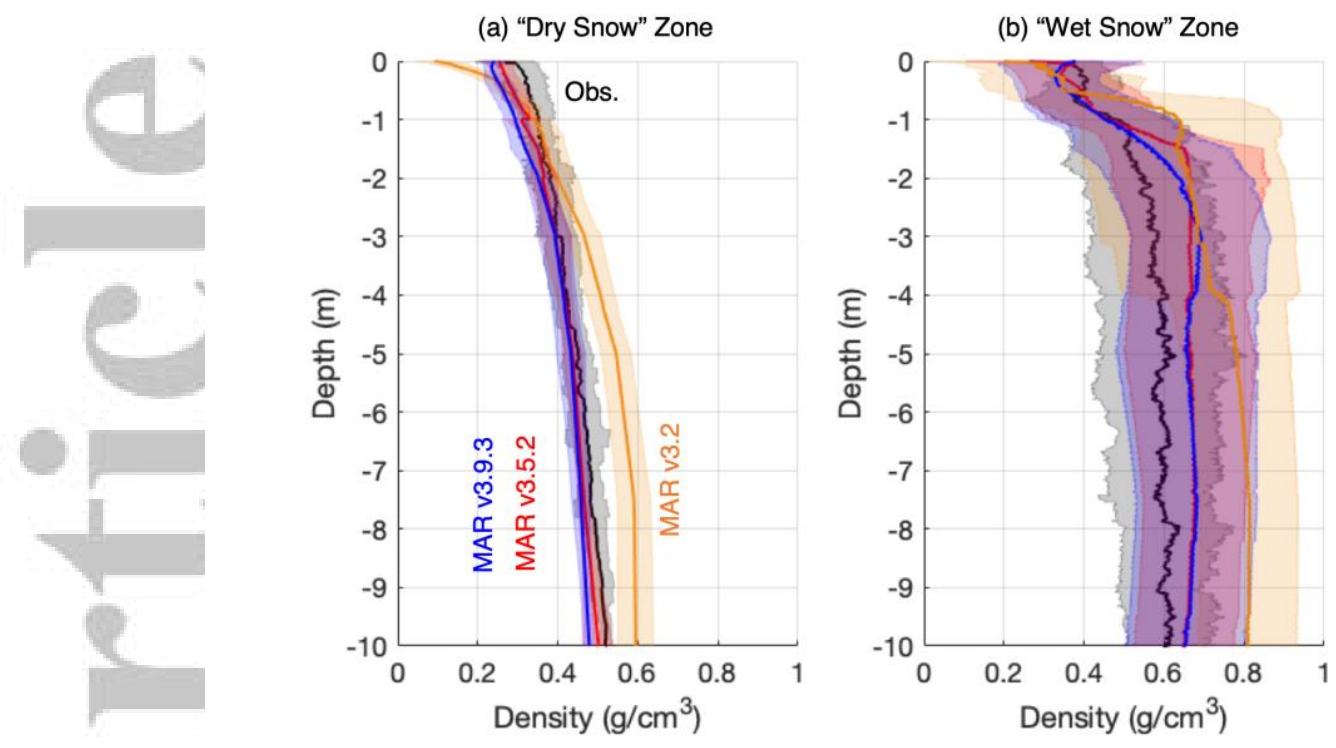

Figure 3: Average density profiles for different versions of the MAR RCM (a) for dry snow locations from MAR v3.2, v3.5.2, and v3.9.3 and (b) same as (a) for wet snow locations.

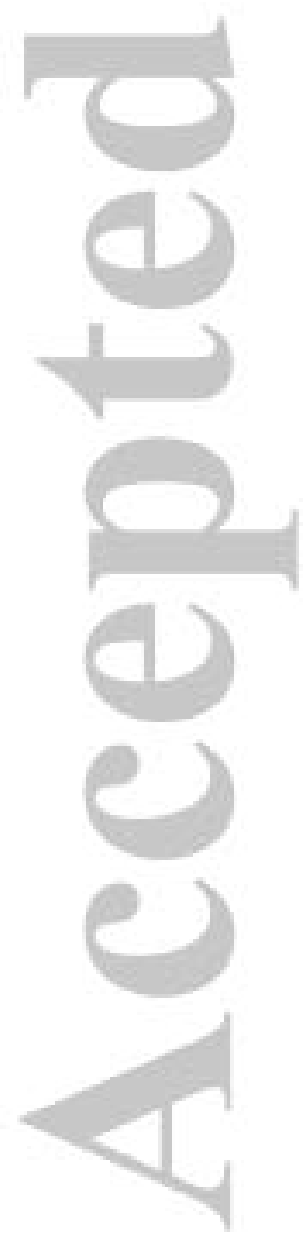

